\title{
Institutional Design in Bosnia and Herzegovina
}

\author{
Ljiljana Aulić ${ }^{1}$
}

Zoran Kalinić ${ }^{2}$

\begin{abstract}
The authors of the paper have been studing the electoral engineering in Bosnia and Herzegovina, where the formal rules define the behavior of parties, politicians and citizens. In the first part of the hypothesis is tested whether the institutional design of Bosnia and Herzegovina contributes to the strengthening of democracy and its consolidation. We discuss the key dilemmas and challenges of the Constitution of $\mathrm{BiH}$, as well as the electoral system where we've provided concrete examples of electoral engineering. In the second part of the paper the authors state the causes and consequences of electoral engineering in Bosnia and Herzegovina, where attention is given to the institutional design. The aim is to point out the necessary reforms of the electoral system, which is expected to reduce ethnic conflicts, the creation of democratic accountability, solving social problems, strengthening the will and confidence of voters, as well as increasing women's quota in institutions. At the end of the work we point out the solutions, with the intention that the work will serve and contribute the scientific knowledge of institutional design in Bosnia and Herzegovina.
\end{abstract}

KEY WORDS: Constitution of Bosnia and Herzegovina, institutional design, election engineering in $\mathrm{BiH}$, electoral manipulation, the strategy of political parties

\section{INTRODUCTION}

Establishing of democratic systems in the post-communist countries, is the result of: splitting of federations, demolition of authoritarian leaders, constitutional changes, the introduction of the multiparty system and the competitiveness of the party, democratic elections and the introduction of market economy. After the demolition of the essential characteristics of communist ideology, the establishment of democratic systems was coming to the surface through the various ways, with the help of new constitution suitable for building a stable democracy and in the case of Bosnia and Herzegovina civil war. If we analyze the consequences of the civil war in Bosnia-Herzegovina, it appears that all sides in the conflict have suffered heavy casualties and destruction, and that

\footnotetext{
${ }^{1}$ Ljiljana Aulić, PhD. Student, Faculty of Political Science, Independent University of Banja Luka, Veljka Mlađenovića 12 e, Banja Luka, Republika Srpska, Bosnia and Herzegovina, e-mail: ljiljana.aulic@gmail.com

2 Zoran Kalinić, PhD. Faculty of Political Science, Independent University of Banja Luka, Veljka Mlađenovića 12 e, Banja Luka, Republika Srpska, Bosnia and Herzegovina, e-mail: kaliniczoran@gmail.com
} 
international law of war was not respected by all participants (Milutinović, 2016). So, the last decade of the 20th century brought a historic change. The world order was changed, ideology, maps, wars with no winners, as well, there were a lot of divisions: national, ethnic and cultural.

Changes began by adopting new democratic constitutions which guaranteed the establishment of a democratic political system. The exception does not change the rules, and after the Civil War (1992-1995) by Annex 4 of the Dayton Peace Agreement, Bosnia and Herzegovina was costituted. The difference in the adoption of the constitution of the state is evident in the name of the Constitution, which is as usually takes in the Parliament of the state of Bosnia and Herzegovina, on the part of the General Peace Agreement, which was aimed primarily at the ending of the conflict. No doubt, the Constitution of Bosnia and Herzegovina was the result of international arbitration and compromise of nations (Serbs, Muslims and Croats) in the conditions that were active in those days, and the authors of the Dayton Peace Agreement, a majority were American diplomats, knew the causes of breaking up Yugoslavia and the consequences of inter-ethnic and religious conflict in Bosnia i Herzegovina. Perhaps the best description of the situation in $\mathrm{BiH}$ is described by Cicero's words "that everything is horrible in the civil war, and the most awful is to win."

Starting from the general social and political situation in which Bosnia and Herzegovina is today, which is by the opinion of many international and domestic subjects in permanent crisis, mainly associated with the constitutional model of Bosnia and Herzegovina. The changes required are mostly opposing position of constituent nations and their ethnicity. And 20 years after of the General Peace Agreement, belonging to a particular collectivity, it is the primar category of the constitutional structure of Bosnia and Herzegovina as a state, the two entities, the Federation of Bosnia and Herzegovina, The Republika Srpska and the District of Brčko.

The subject of the research of this work is the institutional design in Bosnia and Herzegovina, which is subject to electoral engineering and manipulations that accompany the elections in Bosnia and Herzegovina. The institutional design of Bosnia and Herzegovina is specific and complex. For these reasons, the very nature of the political system, many academic papers of Bosnia and Herzegovina, is talking about unfinished, impossible, and divided country. In the paper we write about the political structure of Bosnia and Herzegovina, the essential characteristics defined by the Constitution, and its amendments, which are the framework of institutional design which original shape was defined in 1995 , and afterall has been significantly changed. With the help of the decision and the laws passed by the Office of High Representative (OHR), many of entity competencies were transferred to the state level. Today, the seized jurisdiction 
are reasons for many disagreements and guided manipulation among party elites of Bosnia and Herzegovina.

In the conditions of democratic political system, institutional design is essential for the stability of the system and its strengthening. Larry Diamond talked about the causal relationship between democracy and people, that democracy requires popular support, and support comes from legitimacy. The institutional structure provides the framework within which political actorsparties use the power and the tools available to them to obtain power, concentration of power or participation in government.

Thus, the hypothesis in this paper is whether the institutional design of Bosnia and Herzegovina contributes to the strengthening of democracy and its consolidation. A special hypothesis is whether the characteristics of the political system of Bosnia and Herzegovina conducive to the political actors to poor quality of democracy in the country. The main part of the work will focus on electoral engineering, where we looked at the problem through theory and rational choice of institutionalism. In conclusion we give an answer to the hypotheses, taking the main features of institutional design that is used as a strategy of political parties to stay in power and maintain the concentration of political power.

\section{THE CONSTITUTIONAL ARRANGEMENT OF BOSNIA AND HERZEGOVINA}

The complex organizational and functional structure of the State that is established upon the state Constitution is not an expression of the unity of the Bosnian society, but an expression of its deep division that draws on religious, ethnic or national origin. This is confirmed by the fact that people in Bosnia and Herzegovina speak the same language, and that the division was created on religious grounds, where they become Orthodox Serbs, Muslim Bosniaks and Catholic Croats.

The political system of Bosnia and Herzegovina lies in the political system of representative democracy and it is measured by the majority and the so-called of the consociational democracy. Model of the consociational democracy has been developed by Arendt Lijphart, as a set of institutional arrangements for ensuring democracy in plural societies, divided by deep racial, ethnic, religious or linguistic cleavages. And today in his work can be read that he is confident that consociational democracy or as also called "democracy of the split power" is not only the optimal form of democracy for deeply divided societies, but also the only possible solution for the most deeply divided societies (Lijphart, 2002, p. 37; Lijphart, 2004). The basic elements of consociational democracy are the separation of powers, and the participation of representatives of all relevant 
social groups in the political decision-making, especially at the executive level. Then, group autonomy, powers of every important social groups to self-regulate its own affairs, especially in the area of education and culture. Furthermore, proportional representation in legislative and executive authorities and the minority veto on the most important areas related to the rights of minorities and its autonomy (Lijphart, 2002, pp. 38-39)

The elements of consociational democracy in the Constitution of Bosnia and Herzegovina are those provisions and regulations of the Constitution that establishes the right of all constituent nations to have their representatives in the $\mathrm{BiH}$ authorities. There are also provisions regulating specific rights that accompany all constituent nations.

According to the article IV / 1 of the Constitution of BiH House of Common (the upper legislative chamber) of the Parliamentary Assembly of Bosnia and Herzegovina has 15 delegates, of which two thirds from the Federation of Bosnia and Herzegovina (including five Croats and five Bosniacs) and one-third from the Republika Srpska (five Serbs). According to Article VI / 3e of the Constitution, the delegates of the Parliamentary Assembly of BiH have relatively veto power, which includes the ability to block the adoption of laws in the Parliamentary Assembly of $\mathrm{BiH}$ on the grounds that the law is "destructive to the vital national interest of their people." Furthermore, in the provisions of Article IX / 3 of the Constitution of $\mathrm{BiH}$ can be found elements of consociational democracy, because it prescribes a structure of the officials in institutions of Bosnia and Herzegovina, which, in essence, should reflect the ethnic structure of $\mathrm{BiH}$. Consociational democracy is recognized in the provisions of Article VI of the Constitution concerning the composition of the Presidency of Bosnia and Herzegovina, as well as the rights managing by members of the Presidency of Bosnia and Herzegovina (Article V/2c Constitution) regarding to decisions of the Presidency, that under this provision of the Constitution, generally, is taken by consensus.

Unlike functioning democracy based on majority, this form of democracy is functioning on the basis of satisfying the interests of different social groups through mutual separation of powers, and especially the rights prescribed for these social entities. The generally accepted characteristics of the consociational democracy are: the autonomy of individual groups, large collation group of parties, proportional representation of all stakeholders in the public and political life, and the right to collective veto on key political decisions.

The consociational model of democracy makes the important dimension of the constitutional organization of power in Bosnia and Herzegovina. It was a crucial segment of the administrative and territorial division, to accept the Dayton Peace Agreement and forms the basis of establishing relations and the division of powers among the constituent nations of $\mathrm{BiH}$. This form of 
democracy is aplicative toward social segmented society on various grounds (e.g. national, religious, ethnic, historical, linguistic, etc.), and opens the possibility of participation of different collectives in the government.

\section{1 Federal elements of Bosnia and Herzegovina}

By BiH Constitution (Article I / 3), the Federation of Bosnia and Herzegovina and the Republika Srpska was declared as the entities that make up the state of Bosnia and Herzegovina, endorsed by the inter-entity boundary line that was formed during the war with certain modifications made by Annex 2 of the Dayton Peace Agreement. On this basis, the Federation of $\mathrm{BiH}$ (which was initially called as a Muslim-Croatian Federation) and the Republika Srpska were territory rounded. It was subsequently followed by an arbitration award on the basis that the Brčko District was formed as a separate territory, which in the territorial sense belongs to the Federation and the Republika Srpska (joint ownership or so called Condominium), and in legal terms is subordinate to the state level of government.

Accordingly, the two entities - the Republika Srpska and the Federation of $\mathrm{BiH}$ and Brčko District are based on the territorial principle and are the constituent elements of the state, which clearly indicates that this is a complicated country. The division of the national territory and part of ethnonational constitutional system monitors the organizational structure of government dominated by the federal principle. In the complex states, particulary federations, the essential question of the constitutional system represents the division of responsibilities between the state and its subjectivity ie. between different political and territorial levels of government. The division of jurisdiction determines which political and territorial level of government to what extent and in which areas it is in power. According to the Constitution of $\mathrm{BiH}$ entities have a special position in the division of responsibilities between the "institutions of Bosnia and Herzegovina" and entities.

We should not forget that in the after-Dayton period have been made a very significant factual changes to the Constitution. The procedure was not carried through constitutional amendment pursuant to Article X of the Constitution of $\mathrm{BiH}$, but through the transfer or the transfer of competences from the entities to the state institutions. The transfer or assumption of jurisdiction was carried out in the form of a law by using "legal violence" by the OHR, in small part, on the basis of approval issuing entities (Kunić, 2015).

This process of imposing solutions by the OHR through the political pressures, and various international actors, particularly was intensified in the period from 2000 to 2006 . Very often, the reason for the imposed changes that have occurred very quickly, was packaged in the country's European future (EU). The most significant changes have occurred regarding the decision of the 
Constitutional Court with the Decision on Constituent Nations, The Decision on State Property and many others, which led to the establishment of new institutions at the state level as well as the agencies for monitoring them. It is quite clear that the administration at the state level was expanding and increasingly strained budget. Today is a big problem in the bulkiness of its functionality and coordination mechanism, as well as its uneconomical. So, it's about changes in the Constitution that significantly modified the constitutional structure of the country in relation to its original plan (annex 4 of the General Framework Agreement). We can conclude that this form of transfer of competencies from the entities to the state in the post-Dayton time with the application of the principle of non-democratic elements significantly reduce the confederal structure of $\mathrm{BiH}$, in favor of strengthening the capacity of government institutions and federal state.

\section{INSTITUTIONAL DESIGN IN DIVIDED SOCIETIES}

The disintegration of authoritarian system since the mid-70s of the twentieth century, with the third wave of democratization that was marked by the culmination of the fall of communism, there was a need for new knowledge about designing political institutions. The institutional design as a special theoretical line in political science, is focused on reflection and resolve fundamental institutional problems of contemporary societies. Institutional design is not just a matter of constitutional and institutional challenges and dilemmas after the collapse of the old regime, but also a part of solving the existing problems and the "overhaul" of the political institutions in the central stages of democratic transition, in circumstances where have not happened, yet, the consolidation of democracy (Kasapović, 2004, p. 109) .

Constitutional design (engineering) includes procedural and substantive aspects of the adoption of the Constitution, as we wrote in the first part of the paper. Constitutional engineering involves not only the Constitution as the supreme law of the state, but a wider organization of the political community and the fundamental political institutions. Sartori, Lijphart and Horowitz believe that the institutional and constitutional design are the same thing.

Therefore, the institutional design as a discipline of political science is the study of key issues:

1. how political institutions act as levers of conflict management in divided societies;

2. if the Costitutions of divided societies can be designed to contribute to mutual adjustment of diverse communities and strengthening democracy;

3 . the way the certain political institutions act on democratization of divided societies (Reynolds, 2002, pp. 1-2). 
A significant number of prominent political scientists worked on institutional design, which in the opinion of Mirjana Kasapović wouldn't have been developed so quickly and would not have assumed such significance that there was no strong practical reasons and challenges. So we emphasize Sartori, Lijphart, Linz, Horowitz, Diamond, Reynolds and Reilly, whose findings we used for work purposes.

Giovanni Sartori in his book Comparative Constitutional Engineering is committed to engaging a political scientist about constitutional engineering, and in conceiving and designing political institutions and the political systems in their countries as a political engineer (builder), or political designers. For Sartori the Constitutions are machines or mechanisms that must work well, based on reward and punishment. In this regard, they should be constructed as such. $\mathrm{He}$ calls on political scientists to intervene in the design of political institutions and political systems. The only serious obstacle on this path should be incompetence and ineptitude.

The theory of consociational democracy Arend Lijphart $(1984,1999)$, which we discussed in details in the first part of the work is still the framework within which debate on institutional design. Lijphart lists down nine areas of constitutional elections in divided societies:

First, the area of the electoral system for the legislature, it supports the proportional system of elections to secure a representative parliament, which is considered as a key condition for survival of divided societies;

Second, within the broad categories of proportional electoral system it supports the system that "maximizes proportionality" and it is based on the competition within closed electoral lists, which encourages the emergence of a strong and cohesive political parties;

Third, explicitly advocates a parliamentary system of government, rejecting any form of presidential or semi-presidential system;

Fourth, encourages the sharing of executive power, creating a large coalition government with the participation of all major political parties;

Fifth, advocates the institutionalization of mechanisms to ensure the sustainability and stability of government;

Sixth, it preferres the choice of the president in parliament, not in the general election because they are a source of democratic legitimacy of the head of state, and it is lining its conversion from a ceremonial figure in active political participant, and crossing from parliamentary to semi-parliamentary system of government;

Seventh, supports the federal and decentralized system of government as the best way of institutional ensuring of the group autonomy, and a bicameral parliament as an expression of its condition; 
Eighth, advocates for non-territorial autonomy in divided societies where minority social groups are geographically dispersed in the form of financial support from the state to schools, cultural institutions and other minority institutions and organizations;

Ninth, the insurance of division of power between different social groups and outside parliament and the government, i.e. in the army, police, judiciary and elsewhere with the help of ethnic quotas and other representation.

Donald Horowitz criticizes Lijphart claiming that the consociational theory is not a fruitful way for constitutional engineers quoting:

First, the consociational approach is motivationally unacceptable, because the leaders of the majority community in a divided society, who have the support of the majority and can have all the power in the state, are not motivated by powersharing with the minority communities, therefore, they are not interested to conclude large or all-parties post-election coalitions as a central element of consociational theory.

Second, it is highly questionable assumption that the political elite in divided societies are more tolerant than ethnic groups they represent.

Third, to compromise over ethnic dividing line is usually very expensive and cause opposition and resistance counter- elite within ethnic groups.

Fourth, if the grand coalition, proportional division of resources, the division of executive power and the minority veto are motivational problem, cultural autonomy of ethnic groups is a structural problem.

Fifth, Lijphart considers that Horowitz neglects the difference between the election and post election coalitions. All his coalitions are post-election coalition, however, are based on a compromise on the division of portfolios, not to compromise on the resolution of interethnic problems (Lijphart, 2002, p. 19).

Benjamin Reilly stands out centripetalism as a normative theory of institutional design, which is based on the support of three phenomena in divided societies: 1. Election motive of political actors to conduct a moderate policy that attracted the votes of ethnic groups; 2 . The arena of negotiation in which different ethnic actors agree on political and social issues that transcend party and ethnic divisions; 3 . The Political parties of center and coalitions which are aimed at obtaining a multiethnic support for their policy (Reilly, 2001, p. 11). He is committed to the support of accommodation and cooperation among different ethnic groups in the election itself.

The theory of the new institutionalism defined political institutions as independent political actors that influence the results of the political process (March, Olsen, 1984). Considering that the change of institutions results in changing of forms of political behavior and political practice of other individual and collective actors. Democracy by this theory depends on the design of political institutions. Given the above, it is necessary to pre-conceive and 
implement mechanisms that will change the patterns of political behavior and political practice in conflict societies.

\subsection{Electiorial design as a branch of institutional design}

An integral part of the institutional design is the electoral design. The electoral system is a set of rules determining when and how to vote, and the way the votes of electors turned into mandates. According to Lijphart electoral system is an essential element of representative democracy. Electoral systems are not only most manipulative instrument of politics, but also shape the party system and affect the determination of representation (Sartori, 2003, p. 14). Slaviša Orlović considers that in the election system it is possible to manipulate the objectives and prospects, privileging one side and discrimination of the another, favoring one and defavoring other actors.

Reilly and Raynolds argue that the well thought-out electoral system is a key of new constitutional democracy. According Arend Lijphart, there are two basic choices faced by the creators of the new democratic constitution, the first, choice of the majority and proportional electoral system, second, choice of parliamentary and presidential form of government (Lijphart, 1991). For him, there are four main dimensions of electoral systems: electoral formula, the transposition of votes into seats, the number of representatives to be elected in the constituency, the electoral census and the size of Parliament - the number of deputies of a legislature (Lijphart, 1994, pp. 10-12).

The majority electoral formula may be a simple majority, an absolute majority and the alternative vote. While the proportional system is the largest remainder formula, the system of the largest average and the single transferable vote. The constituencies vary in number and size, and mandate that it should be divided in. The number of representatives to be elected is of crucial importance for the proportional system, because the smaller the constituency, the smaller the effect of the proportionality of the electoral system. So, it is the way to reduce chances of small parties to enter parliament. Or, the less the representatives are elected in one constituency, the higher the percentage of votes is needed a party to win a mandate / e.the mayority electoral systems reduce the number of parties, while a proportional increases it.

Proportional electoral system and larger constituencies increasing ideological orientation of political parties, their coherence, when voters are allowed the preferential voting, choosing candidates from the same party. It is clear that the form of the electoral system influence the specificity of the country. 


\section{ELECTORAL ENGINEERING IN BOSNIA AND HERZEGOVINA}

The electoral system is one of the most important elements of the political system. The electoral system is reflected in the behavior of: voters, politicians, election results, party system, the method of selecting government and its stability, the representation of different groups in society and their interests. According to Sartori, the current practice shows that the re-engineering and the choice of the electoral system was particularly important and significant for the (re) constitution of democracy in post-communist countries. In Bosnia and Herzegovina in the postwar period was established an electoral system that reflected the conditions and the social dynamics of the time.

Political institutions set the rules according to which democracy is implemented, and it is often argued that the electoral system is a political institution, which is the easiest to manipulate. The electoral system, the adjustment of the vote in the legislature, in fact decide who is elected and which party gains power.

The Parliamentary Assembly of $\mathrm{BiH}$ as a legislative body is composed of two chambers: the House of Representatives and The House of Common. The total number of delegates to the Parliamentary Assembly of $\mathrm{BiH}$ is 57, which is a small number regarding to the assessment of the population of the Agency for Statistics of $\mathrm{BiH}$ from 2011 in the number of 3,843,126. It is important to note that the SRBiH elected in 1990 consisted of 240 seats (130 in the Council of 110 citizens and municipalities in the Council) (Arnautović, 1996, p. 108). Table 1 shows the structure of political parties in the Parliamentary Assembly of Bosnia and Herzegovina according to the 2014 general elections.

The Election Law of Bosnia and Herzegovina with all its changes and amendments (a total of 22 amendments), its provisions regulate and establish the principles for the election at all levels of government complex structure of $\mathrm{BiH}$. Chapter 2 of the Election Law of $\mathrm{BiH}$ defines that $\mathrm{BiH}$ authorities are responsible for implementing of ellections- the election commission and the electoral committees.

The Central Election Commission of Bosnia and Herzegovina (CIK BiH) is an umbrella, it is constant in the structure of the electoral authority in Bosnia and Herzegovina. The constant election officials are also election commission of basic constituencies and centers for voters' list in each municipality or city in $\mathrm{BiH}$. The Centers for voter lists are formed for each municipality / city within the government administration. The implementing regulation which is directly related to the work of electoral committees and the mobile teams of the ordinance is also the Book of rules of the conduct of elections in Bosnia and Herzegovina. 
Table 1: Parliamentary Assembly of Bosnia and Herzegovina-structure of political parties

\begin{tabular}{|l|l|l|l|}
\hline Political party - Coalition & from FBiH & from RS & total \\
\hline SDA - Party of democratic activity & 12 & 1 & 13 \\
\hline $\begin{array}{l}\text { The Alliance of Independent Social Democrats } \\
\text { - SNSD - Milorad Dodik }\end{array}$ & - & 8 & 8 \\
\hline Democratic Front - Željko Komšić & 6 & - & 6 \\
\hline SDS-Srbian democratic party & - & 7 & 7 \\
\hline $\begin{array}{l}\text { SBB - Aliance for the better BiH - Fahrudin } \\
\text { Radončic }\end{array}$ & 5 & - & 5 \\
\hline $\begin{array}{l}\text { Coalition of HDZ BiH, HSS, HKDU BiH, HSP } \\
\text { dr. Ante Starčević, HSP, Herceg - Bosna }\end{array}$ & 8 & - & 8 \\
\hline SDPBiH -Social democratic party of BiH & 3 & - & 3 \\
\hline HDZ 1990 -Croatian democratic union 1990. & 2 & - & 2 \\
\hline BPS - BiH Patriotic Party - Sefer Halilović & 1 & - & 1 \\
\hline A-SDA - Party of Democratic Activity & 1 & - & 1 \\
\hline $\begin{array}{l}\text { PDP - NDP - Party of Democratic Progress - } \\
\text { TheNational Democratic Movement }\end{array}$ & 1 & - & 1 \\
\hline $\begin{array}{l}\text { DNS - Party of Democratic Progress - } \\
\text { TheNational Democratic Movement }\end{array}$ & - & 2 & 2 \\
\hline Total & 38 & 19 & 57 \\
\hline
\end{tabular}

Source: Opšti izbori 2014 izvor:/www.parlament.ba/sadrzaj/about/general_info

Table 2: Gender structure of the Parliamentary Assembly of BiH 2014.

\begin{tabular}{|c|c|c|}
\hline Men & 45 & $79 \%$ \\
\hline Women & 12 & $21 \%$ \\
\hline Total & 57 & $100 \%$ \\
\hline
\end{tabular}

Source: /www.parlament.ba/sadrzaj/about/general_info

Those familiar with election procedures will argue rightly that Bosnia and Herzegovina is subject to electoral engineering. As time has passed by, or the implementation of the electoral cycle, the election committees are becoming less important electoral process. A large number of political entities - participants in the elections, the fact is increasingly recognized for various manipulations used "gray zone" and the vagueness of the provisions of the BiH Election Law and by-laws in order to create space for manipulation. The authors are opting for a descriptive analysis of texts on electoral manipulations that are in the form of collections of copyright works printed with the help of the European Union. It is known that in recent years in several election held conferences and thematic meetings of the election administration an important topic was election boards 
and shortcomings in their work. Some of the suggestions for correcting the polling committee will be stated in the work.

Very distinctive and striking fact is that many political entities their participation in the elections certified solely for the purpose of various arrangements with positions in polling boards. The smaller part can be identified in all the possible variants of manipulation: the exchange of positions in the electoral committees, trade, invisible political entities that are within a single constituency had dozens of times PSC members and accredited observers than the total votes won in the entire constituency for the level candidacy, etc.

The consequences of the aforementioned behavior of political subjects in practice resulted that in certain polling stations worked quite one-party electoral committees and the vast majority of polling stations electoral committees that were in its composition had more than one representative of the same political entity. This fact is in direct contradiction with Article 2.19, Paragraph (13), the $\mathrm{BiH}$ Election Law, which limits voting committee membership to one member in front of a political entity. This implies a series of questions that may relate to procedures of governing the certification of political entities to participate in the elections and revision of full equality in the allocation of positions in the electoral committees. As a possible solution for the irregularities in the work of the Election Committee would be excluded if the position of the president of the voting committee and his deputy were professionalized or half-professionalized and / or to approach to the formation of regional or city centers for the counting of votes and the reselection electoral activities to be done because they are so far undder the jurisdiction of the electoral committee at the polling station.

Election fraud can be defined as the set of election manipulation that ultimately affect the election results,and a single electoral manipulation as a deliberate action taken by the electoral actors in order to gain an advantage over other political entity. There should be added and election irregularities, unlike manipulation, may be inadvertent mistakes made by election stakeholders, as a result of a lack of understanding of the electoral rules, ignorance or poor training.

Some of the famous electoral manipulations in $\mathrm{BiH}$ that are recognized as part of the electoral engineering, we will only count down, so in addition to manipulation of the voting committee are known:

- Changes to the boundaries and size of constituencies is something that can be the subject of electoral manipulation in a broader sense "electoral engineering". This phenomenon, however, is not easy to prove and requires the application of several statistical methods and the calculation of trend in the distribution of seats in several election cycles and with more than one variable.

- In electoral manipulations that directly affect the election results (electoral fraud), could serve as an example to those that are from closed unblocked list (colloquially open list) in $\mathrm{BiH}$ made absurd that local tycoons and the powerful 
persons influence who will go from an open list into the Parliament or local assembly, rather than the voters themselves.

- Adding of preference votes;

- „Carousel“" voting or so called The Bulgarian train;

- Classic votes buying;

- Voting in the elections instead of those who haven't woted;

- Cancellation of valid ballots;

- Re-registration of a large number of voters;

- Buying of the electoral committees.

In $\mathrm{BiH}$ has been established a proportional electoral system with a number of multi-seat units, which is mainly caused by the complicated political system, and the constitutional architecture of $\mathrm{BiH}$. Specifically, mainly due to two-antity models, which is followed by multi-member constituencies, it was necessary to determine the coexistence of compensatory and proportional electoral system. Thanks to compensatory electoral system occurred virtually, which is not a normal practice, of mixing two levels of electoral census (3-5\%)

$\mathrm{BiH}$ electoral system is a combination of almost all well-known election principles; the majority principle and one-member constituencies for the election of the Presidency of $\mathrm{BiH}$, then the principle of proportional multi-member constituencies for the election of the composition of Parliament, the threshold of $3 \%$ for regular mandates through a closed list of preference, preferential voting (voters are opened), and the 5\% threshold for compensatory mandates, making $\mathrm{BiH}$ electoral system can be considered as a combined electoral system. The following tables give the structure of political winner for the Presidency, then both entities of the Republika Srpska and the Federation of BiH for the members of the Parliamentary Assembly of BiH. To give a better overview of election winners who have won power in more than one term in the table displays the general elections of 2010 and 2014.

Table 3: The Precidency of Bosnia and Herzegovina confirmed Results of the General election 2010 and 2014

\begin{tabular}{|c|c|c|c|c|c|}
\hline \multicolumn{3}{|c|}{ General election 2014} & \multicolumn{3}{|c|}{ General election 2010} \\
\hline $\begin{array}{l}\text { Presidenc } \\
\text { y of } \mathrm{BiH}\end{array}$ & $\begin{array}{l}\text { Candidate/part } \\
\mathrm{y} / \\
\text { coalition }\end{array}$ & $\begin{array}{l}\text { Votes } \\
\%\end{array}$ & $\begin{array}{l}\text { Presidenc } \\
\text { y of } \mathrm{BiH}\end{array}$ & $\begin{array}{l}\text { Candidate/part } \\
\mathrm{y} \\
\text { /coalition }\end{array}$ & Votes $\%$ \\
\hline $\begin{array}{l}\text { Serbian } \\
\text { member }\end{array}$ & $\begin{array}{l}\text { Mladen Ivanić } \\
\text { Savez za } \\
\text { promjene }\end{array}$ & $\begin{array}{l}317.799 \\
48,69 \%\end{array}$ & $\begin{array}{l}\text { Sebian } \\
\text { member }\end{array}$ & $\begin{array}{l}\text { Nebojša } \\
\text { Radmanović } \\
\text { SNSD-SP }\end{array}$ & $\begin{array}{l}295.629 \\
48,92 \%\end{array}$ \\
\hline $\begin{array}{l}\text { Bosniak } \\
\text { member }\end{array}$ & $\begin{array}{l}\text { Bakir } \\
\text { Izetbegović } \\
\text { SDA }\end{array}$ & $\begin{array}{l}247.235 \\
32,87 \%\end{array}$ & $\begin{array}{l}\text { Bosniak } \\
\text { member }\end{array}$ & $\begin{array}{l}\text { Bakir } \\
\text { Izetbegović } \\
\text { SDA }\end{array}$ & $\begin{array}{l}162.831 \\
34,86 \%\end{array}$ \\
\hline
\end{tabular}




\begin{tabular}{|l|l|l|l|l|l|}
\hline $\begin{array}{l}\text { Croatian } \\
\text { member }\end{array}$ & Dragan Čović & 128.053 & $\begin{array}{l}\text { Croatian } \\
\text { member }\end{array}$ & Željko Komšić & $\begin{array}{l}337.065 \\
60,61 \%\end{array}$ \\
\hline
\end{tabular}

Source: Izbori, www.izbori.ba

Table 4: The House of Representatives of the Parliamentary Assembly of Bosnia and Herzegovina / Republika Srpska

\begin{tabular}{|c|c|c|c|c|c|}
\hline \multicolumn{6}{|c|}{ General election 2014} \\
\hline $\begin{array}{l}\text { Name of the party of political } \\
\text { entity }\end{array}$ & Votes & $\%$ & $\begin{array}{c}\text { Manda } \\
\text { te }\end{array}$ & $\begin{array}{c}\text { Direc } \\
\mathbf{t}\end{array}$ & $\begin{array}{c}\text { Compens } \\
\text { ate }\end{array}$ \\
\hline $\begin{array}{l}\text { The Alliance of Independent } \\
\text { Social Democrats -SNSD- } \\
\text { MILORAD DODIK }\end{array}$ & $\begin{array}{l}249 \\
182\end{array}$ & $\begin{array}{c}38,4 \\
8\end{array}$ & 6 & 5 & 1 \\
\hline SDS- Srbian democratic party & $\begin{array}{l}211 \\
562\end{array}$ & $\begin{array}{c}32,6 \\
7\end{array}$ & 5 & 4 & 1 \\
\hline PDP-NDP & 50322 & 7,77 & 1 & & 1 \\
\hline $\begin{array}{l}\text { DNS- Party of Democratic } \\
\text { Progress - TheNational } \\
\text { Democratic Movement }\end{array}$ & 37052 & 5,72 & 1 & & 1 \\
\hline $\begin{array}{l}\text { SDA- Party of democratic } \\
\text { activity }\end{array}$ & 31337 & 4,84 & 1 & & 1 \\
\hline \multicolumn{6}{|c|}{ General election 2010} \\
\hline Name party of political entity & Votes & $\%$ & $\begin{array}{c}\text { Manda } \\
\text { te }\end{array}$ & $\begin{array}{c}\text { Direc } \\
\mathbf{t}\end{array}$ & $\begin{array}{l}\text { Compens } \\
\text { ate }\end{array}$ \\
\hline $\begin{array}{l}\text { The Alliance of Independent } \\
\text { Social Democrats --MILORAD } \\
\text { DODIK }\end{array}$ & $\begin{array}{l}269 \\
009\end{array}$ & $\begin{array}{c}43,3 \\
0\end{array}$ & 8 & 6 & 2 \\
\hline SDS- Srbian democratic party & $\begin{array}{l}137 \\
844\end{array}$ & $\begin{array}{c}22,1 \\
9\end{array}$ & 4 & 3 & 1 \\
\hline $\begin{array}{l}\text { PDP- Party of Democratic } \\
\text { Progress }\end{array}$ & 40070 & 6,45 & 1 & & 1 \\
\hline $\begin{array}{l}\text { DNS- The National Democratic } \\
\text { Movement }\end{array}$ & 28511 & 4,59 & 1 & & 1 \\
\hline
\end{tabular}

Source: Izbori, www.izbori.ba 
Table 5: The House of Representatives of the Parliamentary Assembly of Bosnia and Herzegovina / Federation Bosnia and Herzegovina

\begin{tabular}{|c|c|c|c|c|c|}
\hline \multicolumn{6}{|c|}{ General election 2014} \\
\hline Name party of political entity & Votes & $\%$ & $\begin{array}{l}\text { Mand } \\
\text { ate }\end{array}$ & $\begin{array}{c}\text { Dire } \\
\text { et }\end{array}$ & $\begin{array}{c}\text { Compens } \\
\text { ate }\end{array}$ \\
\hline SDA - Party of democratic activity & 274057 & 27,87 & 9 & 7 & 2 \\
\hline $\begin{array}{l}\text { Democratic Front -ŽELLJKO } \\
\text { KOMŠIĆ }\end{array}$ & 150767 & 15,33 & 5 & 4 & 1 \\
\hline SBB-Aliance for the better $\mathrm{BiH}$ - & 142003 & 14,44 & 4 & 3 & 1 \\
\hline $\begin{array}{l}\text { HDZ BIH, HSS, HKDU BIH, HSP } \\
\text { DR ANTE STARČEVIĆ, HSP } \\
\text { HERCEG BOSNE }\end{array}$ & 119468 & 12,15 & 4 & 4 & \\
\hline $\begin{array}{l}\text { SDP-Social democratic party of } \\
\text { BiH }\end{array}$ & 92906 & 9,45 & 3 & 2 & 1 \\
\hline $\begin{array}{l}\text { HDZ } 1990 \text { Croatian democratic } \\
\text { union }\end{array}$ & 40113 & 4,08 & 1 & & 1 \\
\hline BPS-SEFER HALILOVIĆ & 35866 & 3,65 & 1 & & 1 \\
\hline \multicolumn{6}{|c|}{ General election 2010} \\
\hline Name party of political entity & Votes & $\%$ & $\begin{array}{l}\text { Mand } \\
\text { ate }\end{array}$ & $\begin{array}{c}\text { Dire } \\
\text { ct }\end{array}$ & $\begin{array}{c}\text { Compens } \\
\text { ate }\end{array}$ \\
\hline $\begin{array}{l}\text { SDP- Social democratic party of } \\
\text { BiH }\end{array}$ & 266023 & 26,07 & 8 & 6 & 2 \\
\hline SDA-Party of democratic activity & 197922 & 19,40 & 7 & 7 & \\
\hline $\begin{array}{l}\text { Aliance for the better BiH } \\
\text { FAHRUDIN FRADONČIĆ }\end{array}$ & 124114 & 12,16 & 4 & 3 & 1 \\
\hline $\begin{array}{l}\text { HDZ BIH- CROATIAN } \\
\text { DEMOCRATIC UNION OF } \\
\text { BOSNIA AND HERCEGOVINA }\end{array}$ & 112115 & 10,99 & 3 & 2 & 1 \\
\hline $\begin{array}{l}\text { PARTY FOR BOSNIA AND } \\
\text { HERCEGOVINA }\end{array}$ & 74004 & 7,25 & 2 & 1 & 1 \\
\hline $\begin{array}{l}\text { CROATIAN COALITION OF HDZ } \\
\text { 1990- HSP BIH }\end{array}$ & 49549 & 4,86 & 2 & 1 & 1 \\
\hline $\begin{array}{l}\text { People's Party for Work and } \\
\text { Betterment }\end{array}$ & 49050 & 4,81 & 1 & & 1 \\
\hline
\end{tabular}

Source: Izbori, www.izbori.ba

It is evident that in the system of allocation of mandates, it is highlighted the intention of protecting the ethnic collective interests, as opposing to the civil 
sovereignty and the protection of individual rights and interests, including equal active and passive voting rights. For example. The method of electing members of the Presidency of Bosnia and Herzegovina, and the election of delegates to the $\mathrm{BiH}$ House of Common prevents members of "non-constituent" people, national minorities and undeclared candidacy to enter the election proces to these bodies, as the European Court of Human Rights and Freedoms in Strasbourg in the case " Sejdic and Finci "marked opposite to the European Convention for the protection of human rights and fundamental freedoms, and as such should be changed and harmonized with this Convention. The last general presidential and parliamentary elections in $\mathrm{BiH}$ held in October 2014, according to the positions of international institutions were held in a very complicated electoral system. According to the report of the OSCE observation mission "lack of political will to move away from the General Framework Agreement for Peace in 1995 means that important and long-standing deficiencies (electoral system) remain.

After subjected analysis of electoral engineering in Bosnia and Herzegovina, the question is which of the electoral system is optimal for divided societies? The authors accept the answer of Larry Diamond that if any generalization about institutional design is sustainable, given the bloody outcome of many political systems that have sought to exclude the main group of social rift to be ixcluded from the government, it is not advisable to have majority system for countries with deep ethnic, regional, religious or other emotional and polarizing divisions (Diamond, 1999, p. 104).

Thus, the hypothesis in the work "if the institutional design of Bosnia and Herzegovina contributes to the strengthening of democracy and its consolidation" has not been confirmed because of political institutions do not contribute to its stability and consolidation. The fundamental role of the electoral system in a democratic country is to create an organized institutional framework within which to improve and strengthen the democratic system, transparency of the election process and the holding of free and fair elections throughout the country. This result was contributed by a special hypothesis "whether features of the political system of Bosnia and Herzegovina contribute to the political actors to poor quality of democracy in the country", which was confirmed. Explanation of specific hypotheses can be argued. For example. the situation of 2011 when the formation of the Government of the Federation of BiH should be 6 months, and for the formation of the Council of Ministers of 15 months of political negotiations. Or after the general elections of 2014, when recurring crisis of forming the government, until the end of March 2015, more than 5 months after the elections, they formed the government in several cantons of the Federation of $\mathrm{BiH}$ and the $\mathrm{BiH}$ level, which means that the electoral process and implementation of the election results have not been completed in accordance 
with the prescribed deadlines, and political leaders missed to find agreement in the distribution of departments.

Special hypothesis is found a foothold in the theory of rational choice, which base is that people are faced with several courses of action usually do what they believe will give the best overall outcome. Consequently, politicians in divided societies have a strong incentive to play the ethnic card and the status quo, especially at election time to attract and mobilize voters to get power or stay in power. However, one should not forget that elections are the time when it starts to get weighed will of the people. It is an act by which citizens vote to give to or subtract a certain political option to manage them and the state (Kalinić, Kostov 2008: 13).

\section{CONCLUSION}

In this paper, we dealt with the analysis of institutional design that is specific to the case of Bosnia and Herzegovina. We tried to analyze the work of the key elements of electoral engineering. We agreed that Bosnia and Herzegovina is a complex country, which twenty years after of the civil war failed to achieve the required level of democracy for the success of the transition and democratic consolidation. We have confirmed the hypothesis that certain features of the electoral system allows political actors of Bosnia and Herzegovina to poor quality of democracy, which contributes to instability of the institutions. The reasons for this are the national interests of Serbs, Bosniaks and Croats who are opposed.

Bearing in mind that politics is a struggle of ideas or the struggle for power, in this paper we present the winners of the general elections in 2010 and 2014. The election results appear the visible concentration of political power. It is known that people tend to power for various reasons. Goals are usually want to be hiden or concealed. Some seek to power because it brings "a sense of greatness," the other to realize their material and financial and other goals, the third want to impose their religious, ideological and other social values, but rarely are those who want the common good and the collective interest. The example of Bosnia and Herzegovina is very visible as phenomenon that once elected political elite are doing everything to remain in power, using and electoral manipulation, as well. The leaders, after the elections act to require obedience from the masses, which often "are bought" by protection of national interests. However, as long as the mass choice is repeated they are "the legitimate expression of the will of the mass." They were chosen, elected and chosen to do the political power, and the political power in Bosnia and Herzegovina even beyond the central government, which is characteristic of the post-communist countries. 
So, let us review the conclusions on institutional design in Bosnia and Herzegovina: First, the Constitution of $\mathrm{BiH}$ as an essential element of the constitutional structure takes the ethnic representation of constituent people in the authorities, combined with the principle of territorial federalism, trying to establish a balance between civil and ethno-national organization of state power. Second, the decision of the European Court of Human Rights in the case "Sejdic and Finci" requires broadening the collective equality of the constituent people and minority collectivities. As such it does not require major corrections of the Constitution of $\mathrm{BiH}$, but disagreements in the Federation of $\mathrm{BiH}$ about the concept changes have significantly prolonged the deadline for its alignment. The Bosniak and Croatian communities want to take this decision for radical constitutional changes. Third, elections play an important role trying to manage ethnic tensions in multiethnic societies, such as $\mathrm{BiH}$. Fourth, differences in the regulation of political institutions in the system of political parties explain variations in the representation of national interests in the divided country of Bosnia and Herzegovina. Fifth, the electoral system still largely reflects the dominance or supremacy of the ethnic communities in relation to an individual or a citizen, in terms what it means and acts in European societies of parliamentary democracy. Sixth, the electoral system is determined by the provisions and principles underlying the constitutional order of $\mathrm{BiH}$, so any criticism of the electoral system actually starts by criticism of the constitutional order. Seventh, political actors build democracy, but in fact they are interested in maximizing of their potential for political purposes and as a long staying in power. Eighth, political actors, follow their political interest selected, and do not change the election rules, because as such reduce the value of becoming losers. Ninth, the interpretation of permanent political crisis and the blockade of forming the government after the elections of 2010, 2014 and even so, the scene is a long-standing conflict between two political concept, which is enabled incompleteness of electoral legislation. Political space in Bosnia and Herzegovina is the scene of ideological conflict of two concepts about the way of government formation and functioning of the state in general, and it is a consequence of deepening distrust of the possibility of stable institutions which are the main links of democracy.

\section{REFERENCES}

Aneks 3 Dejtonskog mirovnog sporazum, 2016. [online] June 30, 2016. Avalaible at: http://www.oscebih.org/dejtonski_mirovni_sporazum/BS/annex3.htm [Accessed June 30, 2016]

Arnautović, S., 1996. Izbori u BiH-analiza izbornog procesa. Sarajevo: Promocult, Sarajevo. 
Banović, D. and Gavrić, S., 2011. Država, politika i društvo u Bosni i Hercegovini, Analiza postdejtonskog političkog sistema. Sarajevo: University press, Magistrat.

Banović, D. and Gavrić, S., 2012. Parlamentarizam u Bosni i Hercegovini. Sarajevo: FES, Sarajevski otvoreni centar.

Bencun, S. ed., 2015. Izbori u Bosni i Hercegovini: karakteristike i moguća unaprjeđenja (zbornik autorskih radova). Pod Lupom: Studio Printum.

Bieber, F., 2010. Constitutional reform in Bosnia and Herzegovina: preparing for EU accession. Policy brief, April 2010. Brussels: European policy center.

Bieber, F., 2004. Institutionalizing Ethnicity in the Western Balkans Managing Change in Deeply Divided Societies. Paper no.19, February 2004. Flensburg: ECMI.

Birch, S., 2003. Electoral systems and Political Transformation in Post Comunist Europe. New York: Palgrave Macmillan.

Diamond, L., 1999. Developing Democracy, Toward Consolidation. London: The John Hopkins University Press.

Diamond, L. and Plattner, M., 2006. Electoral Systems and Democracy. Baltimore: The Johns Hopkins University Press.

Goodin, R., 1998. The Theory of Institutional design. Canberra: Australian National University.

Fung, A., 2003. Surgey Article: Recipes for Public Spheres: Eight Institutional Design Choices and their Consequences. The Journal of Political Philosophy, 11(3), pp. 338367.

Horowitz, D. L., 2003. Electoral systems: A primer for decision makers. Journal of Democracy, 14(4), pp. 115-127.

Horowitz, D. L., 1985. Ethnic groups in conflict. Berkeley: University of California Press.

Horowitz, D. L., 1991. A democratic South Africa? Constitutional Engineering in a divided society. Berkeley: University of California Press.

Horowitz, D. L., 2002. Constitutional design: Proposals versus processes. In: A. Reynolds, ed. 2002. Architecture of Democracy. Oxford: Oxford University Press. pp. 15-36.

Kelly, N. and Ashiagbor, S., 2011. Political parties and democracy in theoretical and practical perspectives. New York: NDI, USAID.

Klijn, E. H. and Koppenjan, J. F. M. 2006. Institutional design changing institutional features of networks. Public Management Review, 8(1), pp. 141-160.

Kalinić, Z. and Kostov, S., 2008. Kako da pobjedimo na izborima. Banja Luka: NUBL. Kunić, P., 2015. Promjene Ustava Bosne i Hercegovine, pro et contra. Laktaši: Grafomark.

Lijphart, A., 1994. Electoral systems and party systems, a study of twenty seven democracy, 1945-1990. Oxford: Oxford University Press.

Lijphart, A., 1999. Patterns of democracy, Government Forms and Performance in Thirty-six country. New Haven: Yale University Press. 
Lijphart, A., 2002. Negotiation democracy versus consensus democracy: Parallel conclusions and recommendations. European Journal of Political Research, 41, pp. 107 113.

Lijphart, A., 2004. Constitutional design for divided societies. Journal of Democracy, 15(2), pp. 96-109.

March, J. and Olsen, J., 1984. The new institutionalism: Organizational factors in political life. The American Political Science Review, 78(3), pp.734-749.

Milutinović, M., 2016. Politički diskurs izbliza. Banja Luka: NUBL.

Norris, P., 1997. Choosing Electoral Systems: Proportional, Majoritarian and Mixed Systems. International Political Science Review, 18(3), pp. 297-312.

Norris, P., 2004. Electoral Engineering Voting Rules and Political Behaviour. Massachuttes: Harvard University Press.

Orlović, S., 2012. Političke partije i moć. Čigoja: FPN.

Powell, G. B. and Htun, M., 2013. Political Science, Electoral Rules and Democratic Governance. APSA.

Podjela nadležnosti između institucija Bosne i Hercegovine i entiteta, Akademija nauka i umjetnosti Republike Srpske. 2003. Banja Luka: Naučni skupovi, knjiga III.

Pridham, G., 2005. Designing democracy EU enlargement and regime change in Postcommunist Europe. New York: Palgrave Macmillan.

Republika Srpska dvadeset godina razvoja, dostignuća, izazovi, perspektive, Akademija nauka i umjetnosti Republike Srpske. 2012. Banja Luka, Naučni skupovi, Knjiga XXIII. Perry, V. and Keil, S., 2015. Introduction: Bosnia and Herzegovina 20 years after Dayton. International Peacekeeping, 22(5), pp. 463-470.

Powell, B., 2000a. Elections as Instruments of Democracy. New Haven: Yale University Press.

Powell, B., 2000b. Institutional Design, Citizens Preferences and Policy making. Rochester: University of Rochester.

Reilly, B., 2001. Democracy in divided societes electoral engineering for conflict management. Cambridge: Cambridge University Press.

Reilly, B. and Nordlund, P., 2008. Political Parties in Conflict-Prone Societies: Regulation, Engineering and Democratic Development. Tokyo, New York, Paris: UN University Press.

Reilly, B. and Reynolds, A., 2002. Electoral systems and conflict in divided societies. The National Academies Press, National Research Council.

Sartori, G., 1997. Comparative Constitutional Engineering. Second edition, New York: University Press.

Sartori, G., 2003. Uporedni ustavni inženjering, Beograd: Filip Višnjić.

USTAV BIH, 2016. [online] June 30, 2016. Avalaible at:

http://www.ads.gov.ba/v2/index.php?option=com_content\&view $=$ article $\& i d=1951 \% 3$ Austav-bosne-i-hercegovine [Accessed June 30, 2016] 
УCTAB PC, 2016. [online] June 30, 2016. Avalaible at: http://www.narodnaskupstinars.net/sites/default/files/upload/dokumenti/ustav/cir/ustav _republike_srpske.pdf [Accessed June 30, 2016]

USTAV FBIH, 2016. [online] June 30, 2016. Avalaible at: http://www.parlamentfbih.gov.ba/bos/parlament/o_parlamentu/ustavfbih.html [Accessed June 30, 2016]

Zakon o provođenju izbora, 2016. [online] June 30, 2016. Avalaible at: https://www.izbori.ba/Default.aspx?Lang=5 [Accessed June 30, 2016]

Zakon o Savjetu ministara Bosne i Hercegovine, 2016. [online] June 30, 2016. Avalaible at: https://www.izbori.ba/Default.aspx?CategoryID=445\&Lang=5 [Accessed June 30, 2016] 